\title{
A REVISIBILIDADE DA CONCESSÃO DE LICENÇA AMBIENTAL À LUZ DA CONTROVÉRSIA DA DISCRICIONARIEDADE ADMINISTRATIVA DOS ATOS AMBIENTAIS
}

\section{THE REVOCABILITY OF THE ENVIRONMENTAL LICENSE CONCESSION IN THE LIGHT OF THE CONTROVERSY OVER THE ADMINISTRATIVE DISCRETION OF ENVIRONMENTAL ACTS}

\author{
EMERSON AfFONSO dA COSTA MOURA \\ Universidade Federal Rural do Rio de Janeiro \\ emersonacmoura@yahoo.com.br \\ DAVI VAZQUEZ BARREIRA RANZEIRO DE BRAGANÇA \\ Universidade Cândido Mendes (UCAM) \\ davi_braganc@hotmail.com
}

Recibido: 14 de febrero de 2019 / Aceptado: 15 de mayo de 2019

RESUMO: Pretende-se analisar a revisibilidade do ato de concessão de licença ambiental à luz da sua natureza jurídica discricionária ou vinculada. Para tanto, faz-se uma análise da discricionariedade administrativa à luz das suas transformações e sua interface com o direito ambiental. Após um estudo da relação entre licenciamento ambiental e discricionariedade administrativa à luz das diversas concepções da literatura jurídica. Por fim, verifica-se a questão do licenciamento ambiental e a revisibilidade. Conclui-se pela necessidade de estatal (pautada nas medidas preventivas e precaucionais) da licença ambiental concedida, ainda que a mesma esteja em plena vigência do ato concessório, porque as realidades socioeconômicas e ambientais sofrem 
modificações que podem provocar a necessidade da alteração da licença ambiental concedida ou até mesmo sua revisão nas modalidades acima especificadas.

ABSTRACT: It is intended to analyze the revisability of the act of granting an environmental license in light of its discretionary or related legal nature. For this, an analysis of administrative discretion is made in the light of its transformations and its interface with environmental law. After a study of the relationship between environmental licensing and administrative discretion in light of the different conceptions of legal literature. Finally, there is the issue of environmental licensing and revisability. It is concluded that there is a need for a state license (based on preventive and precautionary measures) of the environmental license granted, even though it is in full force of the concession act, because socioeconomic and environmental realities undergo modifications that may lead to the need to change the environmental license granted or even reviewed in the modalities specified above.

RESUM: Es pretén analitzar la possibilitat de revisibilitat de l'acte de concedir una llicència ambiental a la llum del seu caràcter jurídic o discrecional. Per això, es fa una anàlisi de la discreció administrativa a la llum de les seves transformacions i de la seva interfície amb el dret ambiental, després, un estudi de la relació entre les llicències ambientals i la discreció administrativa a la llum de les diferents concepcions de la literatura jurídica i, finalment, hi ha concessió la qüestió de les llicències ambientals i la revisibilitat. Es conclou que hi ha la necessitat d'una llicència estatal (basada en mesures preventives i cautelars) de la llicència ambiental concedida, tot i que estigui en ple vigor de l'acte de concessió, perquè les realitats socioeconòmiques i ambientals sofreixen modificacions que poden conduir a canviar la llicència ambiental concedida o fins i tot revisada en les modalitats especificades anteriorment.

RESUMEN: Se pretende analizar la posibilidad de revisibilidad del acto de otorgar una licencia ambiental a la luz de su naturaleza legal o discrecional. Para 
ello, se realiza un análisis de la discreción administrativa a la luz de sus transformaciones y su interfaz con el derecho ambiental, después, un estudio de la relación entre las licencias ambientales y la discreción administrativa a la luz de las diferentes concepciones de la literatura legal y, finalmente, está la cuestión de las licencias ambientales y la posibilidad de revisión. Se concluye que es necesaria una licencia estatal (basada en medidas preventivas y cautelares) de la licencia ambiental otorgada, aunque esté en plena vigencia del acto de concesión, porque las realidades socioeconómicas y ambientales sufren modificaciones que pueden llevar a la necesidad de cambiar la licencia ambiental otorgada o incluso revisada en las modalidades especificadas anteriormente.

PALAVRAS-CHAVE: Direito Ambiental - Discricionariedade Administrativa — Licença Ambiental — Administração Pública — Revisibilidade.

KEYWORDS: Environmental Law - Administrative Discretionary Environmental license - Public administration — Revisibility.

PARAULES CLAU: Dret ambiental - Discrecional administratiu - Llicència ambiental — Administració Pública — Revisibilitat.

PALABRAS CLAVE: Derecho ambiental - Administrativo discrecional Licencia ambiental — Administración Pública — Revisibilidad.

SUMÁRIO: I. Introdução II. Discricionariedade Administrativa e Direito Ambiental III. Licenciamento Ambiental e Discricionariedade Administrativa IV. Licenciamento Ambiental e Revisibilidade V. Conclusão. VI. Referências.

\section{INTRODUÇÃO}

Sob a égide de uma ordem jurídico-constitucional pautada na proteção e promoção de bens e valores sociais essenciais a coletividade compete aos entes federados brasileiros um complexo de competências que exteriorizam programas, políticas e serviços impostos pela Constituição Federal.

Se destaca, o direito humano-fundamental ao meio ambiente ecologicamente equilibrado que deflagra no sistema de partilha de bens e competências constitucionais, bem como, na regulação estatal, em especial, através da lei 
federal n 6.938/81, o dever de proteção em face de atividades capazes de gerar danos ambientais.

Não obstante, a concessão da licença ambiental tem por finalidade a verificação do atendimento dos requisitos normativos e administrativos necessários à proteção do meio ambiente, porém, não pode importar um direito subjetivo do seu titular a ponto de garantir a sua manutenção em que pese ameaça a proteção e promoção do meio ambiente.

Busca o presente trabalho, analisar a problemática da revisibilidade do ato de concessão de licença ambiental à luz da divergência na literatura acadêmica acerca da sua natureza jurídica como ato discricionário sujeito à liberdade da Administração Ambiental ou vinculado aos bens e valores jurídicos ligados à proteção do meio ambiente.

A análise se concentra na discricionariedade administrativa à luz das suas transformações e sua interface com o direito ambiental, após no estudo da relação entre licenciamento ambiental e discricionariedade administrativa e por fim, da verificação da questão do licenciamento ambiental e a revisibilidade.

\section{DISCRICIONARIEDADE ADMINISTRATIVA E DIREITO AMBIENTAL}

Discricionariedade administrativa pode ser definida como o espaço de liberdade decisória concedida à Administração Pública na eleição entre os indiferentes jurídicos, inserto na esfera de atribuição concedida pela norma jurídica e de acordo com a formulação dos juízos de conveniência e oportunidade promovidos ${ }^{1}$.

Embora se adéque a necessária dinâmica da atividade administrativa, em um contexto de multiplicidade e complexidade das demandas sociais que escapa à previsibilidade do legislador, a existência de um campo de escolha na atuação

\footnotetext{
1 Nesta ordem, compreende o mérito administrativo os juízos formulados pela Administração Pública acerca da conveniência, oportunidade, equidade e demais critérios utilizados na decisão administrativa que são definitivos e inquestionáveis perante o poder Judiciário. DI PIETRO, Maria Sylvia Zanella. Da Discricionariedade Administrativa. São Paulo: Atlas, 1990. p. 92.
} 
administrativo não representa intangibilidade do seu mérito aos limites impostos pela ordem jurídica².

Existem fins esperados e exigíveis da atuação estatal, exteriorizado na realização dos bens e interesses fundamentais da sociedade veiculados pela Constituição, inclusive, com a definição de prioridades e dispêndio dos recursos estatais, que vinculam os poderes públicos construindo no espaço de sua atuação limites objetivos invioláveis ${ }^{3}$.

Transmuta-se, portanto, a concepção da discricionariedade administrativa de uma ampla esfera de escolha na persecução do interesse público não sujeito a controle pelos poderes públicos a um campo de ponderações proporcionais e razoáveis entre os bens e interesses constitucionais, sujeita a controle exercido pelo Poder Judiciário 4 .

Isto importa no estreitamento do mérito administrativo pelas escolhas definidas pela Constituição ou lei que permitam o exercício da opção política capaz de garantir a otimização do grau de legitimidade da decisão administrativa com a integração nos limites de sua competência ao atendimento do interesse público ${ }^{5}$.

\footnotetext{
${ }^{2}$ A liberdade administrativa conferida por uma norma de direito não significa liberdade de eleição entre indiferentes jurídicos, mas a providência do ato capaz de atingir a finalidade da lei que terá seu campo restrito as soluções possíveis de acordo com o caso concreto e adequadas conforme o dever de boa administração. MELLO, Celso Antonio Bandeira de. Discricionariedade e Controle Jurisdicional. São Paulo: Malheiros, 1992. p. 44-48.

${ }^{3}$ Há casos em que a Constituição consagra de forma explícita os fins esperados, como ocorre com a obrigatoriedade da prestação universal da educação fundamental e medicina de urgência, de modo que condicionar sua promoção à discricionariedade administrativa e conformação legislativa seria violação dos direitos individuais e políticos, cujo exercício pressupõe a garantia mínima do bem-estar, que envolve a realização de condições econômicas e sociais básicas. BARCELLOS, Ana Paula de. Constitucionalização das Políticas Públicas em Matéria de Direitos Fundamentais: O Controle Político-Social e o Controle Jurídico no Espaço Democrático, Revista de Direito do Estado. Ano 1. n. 3. 2006. p. 37. MOURA, Emerson Affonso da Costa. Do Controle Jurídico ao Controle Social: Parâmetros a Efetividade dos Direitos Sociais. Revista de Direito Constitucional e Internacional, v. 77, p. 145, 2011.

${ }^{4}$ Neste tocante, cabe ao Poder Judiciário a correção da discricionariedade, apurando a sua conformidade com o Direito, a racionalidade do discurso que a legitima, o atendimento ao código dos valores dominantes e a proporcionalidade na correlação lógica entre motivos, meios e fins, de forma a preservar a escolha do meio menos gravoso e proporcional aos fins a serem alcançados. CUNHA, Rubem Dário Peregrino. A juridicização da discricionariedade administrativa. Salvador: Vercia, 2005. p. 168-172.

${ }^{5}$ Sendo a discricionariedade competência cometida à Administração para integrar a vontade da lei ou Constituição, corresponde a um resíduo de legitimidade da opção política, que terá a alcançada sua legitimidade por sua fundamentação e eficiência, traduzida na melhor realização dos bens e interesses socialmente almejados. MOREIRA NETO, Diogo de Figueiredo. Legitimidade e Discricionariedade. 3 ed. Rio de Janeiro: Forense, 1998. p. 7-8 e 32-33.
} 
Envolve, também, a submissão do espaço decisório ao feixe de princípios constitucionais, que passam a orientar os juízos de valoração do administrador pelos critérios de razoabilidade, isonomia e demais, assegurando a congruência da decisão administrativa ao interesse legal e o impedimento de sua tradução em arbitrariedade $^{6}$.

Ademais, o reconhecimento da submissão imediata da ação administrativa a observância dos preceitos constitucionais conduz à superação da clássica dicotomia entre atos vinculados e discricionários com o redimensionamento da adstrição de todos os atos administrativos a um certo grau de juridicidade, definido pelo estabelecimento de critérios em vista ao equilíbrio entre os poderes ${ }^{7}$.

Por efeito, a discricionariedade administrativa em matéria ambiental acaba sendo orientada pelo direito humano, fundamental e difuso do meio ambiente ecologicamente equilibrado 8 , já que impõe não apenas aos agentes privados econômicos ou não o dever da sua defesa e reparação ${ }^{9}$, mas aos poderes públicos uma série de competências constitucionais ${ }^{10}$, bem como, de deveres específicos ${ }^{11}$ voltados à sua proteção e promoção.

Por efeito, atuação administrativa na tutela dos bens jurídicos ambientais tem sofrido um acréscimo de complexidade em razão da função de sua tutela para as gerações atuais e futuras, mas também sob o ponto de vista estrutural, na medida em que suas decisões necessitam cada vez mais de ajuda técnica,

\footnotetext{
${ }^{6} \mathrm{~A}$ compreensão do Direito como um sistema formado não apenas de regras, mas também por princípios de reconhecida normatividade e inquestionável força vinculante, impôs limitações ao espaço decisório discricionário que passou a ser considerado como um espaço sujeito a ponderação, reservado nos casos difíceis, a concorrência entre princípios. BAPTISTA, Patrícia. Transformações do Direito Administrativo. Rio de Janeiro: Renovar, 2003. p. 91.

${ }^{7}$ Reconhecida que a discricionariedade não é campo imune a jurisdição é definida a densidade do controle mediante o estabelecimento de critérios de uma dinâmica distributiva de tarefas e responsabilidades entre a Administração Pública e o Poder Judiciário. KRELL, Andreas J. Discricionariedade Administrativa e Proteção Ambiental: o controle dos conceitos jurídicos indeterminados e a competência dos órgãos ambientais. Um Estudo Comparativo. Porto Alegre: Livraria do Advogado, 2004. p. 45.

${ }^{8}$ BRASIL, Constituição da República Federativa do Brasil de 05 de Outubro de 1988. Art. 225

${ }^{9}$ BRASIL, Constituição da República Federativa do Brasil de 05 de Outubro de 1988. Art. 170 VI e Art. $225 \S 2$ e 3.

${ }^{10}$ BRASIL, Constituição da República Federativa do Brasil de 05 de Outubro de 1988. Art. 23 VI, Art. 24 VI e Art. 24 VIII.

11 BRASIL, Constituição da República Federativa do Brasil de 05 de Outubro de 1988. Art. 225 $\S \S$.
} 
diante da necessidade de medidas preventivas em face das incertezas científicas quanto às relações causais.

A ordem jurídico-constitucional ambiental é voltada à tutela do risco ambiental através de criação de uma ordem fundamental de prevenção, que tem como função evitar a inércia dos poderes públicos e permitir a gestão dos riscos e perigos ambientais não apenas conhecidos, mas igualmente calculáveis demandando uma atuação efetiva dos poderes públicos. ${ }^{12}$

Sob tal égide, cabe a Administração Ambiental no exercício da discricionariedade administrativa não uma liberdade plena, mas a escolha dentro do espaço de liberdade conformativo deixado pelo legislador, eleger dentro dos conhecimentos técnicos-científicos, a adoção das medidas e ações públicas específicas e adequadas para a preservação, promoção ou reparação ambiental. ${ }^{13}$

\section{LICENCIAMENTO AMBIENTAL E DISCRICIONARIEDADE}

\section{ADMINISTRATIVA}

Pautada em uma ordem constitucional onde a exploração econômica é realizada de forma direta e imediata pela iniciativa privada e apenas de forma excepcional pelo Estado ${ }^{14}$, o exercício de atividade econômica livre e independe de prévia autorização do Estado, salvo se houver exigência legal em sentido contrário. ${ }^{15}$

Em sua atividade, portanto, eminentemente regulatória compete ao Estado no exercício do seu poder de polícia normativo e administrativo instituir formalmente e atuar de forma administrativa com a concessão, alteração e revogação de licenças e autorizações que encontram regulação normativa em âmbito nacional através da lei federal nº 6.938/81.

\footnotetext{
12 CARVALHO, Délton Winter de. Regulação constitucional e risco ambiental. Revista Brasileira de Direito Constitucional, n. 12, jul./dez. 2008. p. 24.

${ }^{13}$ STEIGLEDER, Annelise Monteiro. Discricionariedade Administrativa e Dever de Proteção ao Meio Ambiente. Revista do Ministério do Estado do Rio Grande do Sul, no 48, jul.-set. 2002. p. 136.

14 BRASIL, Constituição da República Federativa do Brasil de 05 de Outubro de 1988. Art. 173.

15 BRASIL. Constituição da República Federativa do Brasil de 05 de Outubro de 1988. Art. 170, §único.
} 
Destaca-se, que embora a licença administrativa tradicionalmente é dotada da característica de ato administrativo vinculado, uma vez que previstas todas as exigências legais pertinentes deve ser concedida ao seu titular pela Administração Pública, no que tange às licenças ambientais há uma certa divergência doutrinária no que se refere a sua identificação como ato discricionário.

Isto porque, para a concessão de licenças ambientais, o Poder Público deverá proceder a uma análise das respostas complexas e múltiplas apresentadas pelos estudos, e que devem ser avaliadas e sopesadas pelo mesmo. Vê-se, pois, que a discricionariedade é regrada e pautada em critérios técnicos, não podendo implicar nem em caprichosa negativa do administrador àquele que cumpriu com os requisitos legais e para os quais a visão técnica seja favorável, nem em concessão desapegada desta.

Por outro lado, uma vez concedida, a licença não goza da definitividade inerente aos atos de direito administrativo, justamente porque os mesmos estudos técnicos podem, posteriormente, sinalizar em sentido contrário recomendando ou exigindo a cessação da atividade ou a revogação da licença concedida, se assim justificar o interesse público. Isto fica claro nos termos do $\S 4^{\circ}$ do art.14 da Res. 237/97 do Conama: "A renovação de licenças ambientais deve ser requerida com antecedência mínima de 120 (cento e vinte) dias da expiração de seu prazo de validade (...)".

É importante mencionar que tal dever, apesar de ser de iniciativa dos empreendedores, se relaciona ao poder de polícia fiscalizatório do Estado. Isto porque cabe ao órgão ambiental o direito-dever de requisitar informações, documentos e estudos necessários, podendo, inclusive fixar prazos para essa resposta. Caso o empreendedor não atenda à requisição haverá indeferimento da renovação da licença ${ }^{16}$.

Por esta razão, há de se considerar que as licenças administrativas em matérias ambientais possuem natureza jurídica não de ato discricionário, mas de ato

${ }_{16}$ MACHADO, Paulo Affonso de Leme. Direito Ambiental Brasileiro. São Paulo: Malheiros, 2012, p.330. 
vinculado e definitivo, uma vez que não há uma liberdade de escolha do administrador, porém, a sua vinculação a determinados elementos. ${ }^{17}$

Assim, a literatura dominante considera a licença ambiental é um ato declaratório de um direito preexistente e podendo resultar em direito subjetivo do titular, consistente tanto em sua manutenção, quanto em indenização do interessado que, para seu exercício, precisa preencher alguns requisitos previstos em Lei. ${ }^{18}$ Daí decorre que a Administração não pode negá-la quando o requerimento satisfaz todos esses requisitos, sendo, portanto, um ato administrativo vinculado ${ }^{19}$.

Para parte da literatura, porém, a licença ambiental tem natureza híbrida, que ora possui características de verdadeira licença, ora de mera autorização. Assim, tem natureza de definitiva, pois uma vez expedida, goza de estabilidade durante o prazo de vigência, apenas se expirado este, contudo a atividade deve se submeter a novo processo de licenciamento, o que não ocorre com as hipóteses envolvendo boa parte das licenças urbanísticas, como alvarás de construção, por exemplo ${ }^{20}$.

A licença é definitiva, embora possa se sujeitar a prazo de validade, podendo ser, como se analisará adiante, anulada diante de ilegalidade superveniente, cassada quando houver descumprimento de requisitos para o exercício da atividade, e por revogação, se advier interesse público que por razões de conveniência e oportunidade exija a não realização da atividade licenciada, cabendo neste caso, indenização ao particular.

\footnotetext{
17 FINK, Daniel Roberto. Aspectos jurídicos do licenciamento ambiental. 2. Ed. Rio de Janeiro: Forense Universitária, 2002. p. 10.

18 São defensores desse posicionamento jurídico: William Freire - in Direito Ambiental Brasileiro; Édis Milaré - in Direito do Ambiente; Antônio Inagê de Assis - in O Licenciamento Ambiental; Daniel Fink - in Aspectos Jurídicos do Licenciamento Ambiental e Lucia Valle Figueiredo. Licença, mas com certo grau de discricionariedade, motivada. Relação jurídica rebus sic stantibus (RDA 35/51); Ricardo Carneiro; in Direito Ambiental: uma abordagem econômica. Rio de Janeiro: Forense, 2003. QUEIROZ, João Eduardo Lopes. Processo administrativo de licenciamento ambiental - licenciamento ambiental da atividade agropecuária. Exigência de licenciamento para a obtenção de crédito rural

${ }^{19}$ FINK, Daniel Roberto. Aspectos jurídicos do licenciamento ambiental. 2. Ed. Rio de Janeiro: Forense Universitária, 2002. p. 10.

20 DANTAS, Marcelo Buzaglo Dantas. Licenciamento ambiental de atividades produtivas. In: AHAMED, Fávio e COUTINHO, Ronaldo (Org.). Cidades sustentáveis no Brasil e sua tutela jurídica. Rio de Janeiro: Lumen Juris, 2009. p. 41.
} 
Já uma linha mais moderna da literatura jurídica justifica a margem de discricionariedade que é conferida à autoridade ambiental afirmando que não há atos administrativos completamente vinculados ou discricionários, mas uma situação de preponderância, ou seja, a depender da maior ou menor liberdade deliberativa do agente público, irá prevalecer uma ou outra característica. ${ }^{21}$

Dessa forma, esta doutrina procura destacar que caracterizar a licença ambiental como ato discricionário gerará insegurança jurídica e até ameaçará a própria ordem econômica, na medida em que afastaria investimentos. Por outro lado, caracterizá-la como ato vinculado colocaria em risco um valor ainda mais soberano, que é o Direito Fundamental ao meio ambiente ecologicamente equilibrado. O sensato é enquadrar a licença ambiental como um ato administrativo próprio, podendo ser vinculado ou discricionário, já que tem tanto características da autorização como da licença administrativa. ${ }^{22}$

No caso da licença ambiental, embora haja uma inegável margem de discricionariedade da administração pública na análise das condições estabelecidas para a sua concessão, já que estas são dotadas de um alto grau de subjetivismo, deve-se enfatizar que a manifestação administrativa está subordinada ao reconhecimento formal de tais requisitos, ou seja, o deferimento ou não do pedido de licença deve estar fundamentado no preenchimento ou não das condições ambientais legalmente previstas para o exercício da atividade, e não em critérios de oportunidade e conveniência da administração.

Em resumo, tratar-se-ia de uma licença especial, pois apesar de ter prazo de validade estipulado, goza do carácter de estabilidade, de jure; não poderá pois, ser suspensa ou revogada, por simples discricionariedade, muito menos por arbitrariedade do administrador público. Sua renovabilidade não conflita com sua estabilidade; está, porém, sujeita a revisão, podendo ser suspensa e mesmo cancelada, em caso de interesse público ou ilegalidade superveniente ou, ainda, quando houver descumprimento dos requisitos preestabelecidos no processo de licenciamento ambiental. ${ }^{23}$

\footnotetext{
${ }^{21}$ MILARÉ, Édis. Direito do Ambiente. A gestão Ambiental em foco. Doutrina. Jurisprudência. Glossário. 6. ed. rev., atual. e ampl. São Paulo: Editora RT, 2009, p. 426.

${ }^{22}$ Sobre o tema, vide: FARIAS, Talden. Licenciamento Ambiental: aspectos teóricos e práticos. Belo Horizonte: Fórum, 2007.

${ }^{23}$ MILARÉ, Édis. Direito do Ambiente. Op. cit. p. 426.
} 
Assim, a licença ambiental não assegura ao seu titular a manutenção do status quo vigorante ao tempo de sua expedição, sujeitando-se a prazos de validades. O referido autor afirma que "caracteriza-se por uma estabilidade temporal, que não se confunde com a precariedade das autorizações, nem com a definitividade das licenças tradicionais" 24 .

Por essa razão, a licença ambiental, mesmo antes do vencimento de seu prazo de validade, pode ser suspensa ou cancelada diante de hipóteses específicas, tais como o interesse público ou ilegalidade supervenientes, ou mesmo quando o particular descumpre os requisitos que foram estipulados para a concessão.

Outros autores relacionam o licenciamento a uma mera autorização administrativa, posto que esta é ato administrativo discricionário e precário podendo ser revogado a qualquer momento sem que desta revogação se constituam direitos subjetivos ou indenização ${ }^{25}$.

Os autores argumentam, em síntese, que a existência de prazo certo de validade bem como a existência dos termos renovação (art. 10을 $\$ 1^{\circ}$ da Lei $n^{\circ}$ $6.938 / 1981)^{26}$ e revisão (art. 9º , da mesma lei) ${ }^{27}$ torna incompatível a licença administrativa com a licença nos moldes ambientais, implicando no dever de intervir periodicamente para controlar e fiscalizar a qualidade ambiental de uma atividade sujeita ao licenciamento ambiental ${ }^{28}$.

Neste sentido, o Tribunal de Justiça do Estado de São Paulo já decidiu que diante do art. 10, $\S 1^{\circ}$ da Lei $6938 / 81$ o qual prevê o pedido de renovação de licença, indica que se trata de autorização, pois se fosse juridicamente licença, seria ato definitivo, sem necessidade de renovação ${ }^{29}$.

\footnotetext{
24 Idem. Ibidem.

${ }^{25}$ Adotam esse posicionamento: Paulo Affonso Leme Machado. In: Direito Ambiental Brasileiro, Vladimir Passos de Freitas. In: Direito Administrativo e Meio Ambiente e Toshio Mukai. In: Direito Ambiental Sistematizado.

${ }^{26}$ BRASIL. Lei $n^{\circ}$ 6.938/81. "Art.10, $\S 1^{\circ}$ : Os pedidos de licenciamento, sua renovação e a respectiva concessão serão publicados no jornal oficial, bem como em periódico regional ou local de grande circulação, ou em meio eletrônico de comunicação mantido pelo órgão ambiental competente". (Redação dada pela Lei Complementar no 140, de 2011)

${ }^{27}$ BRASIL. Lei $n^{\circ}$ 6.938/81. "Art 9o - São instrumentos da Política Nacional do Meio Ambiente: (...) IV - o licenciamento e a revisão de atividades efetiva ou potencialmente poluidoras";

${ }_{28}$ MACHADO, Paulo Affonso de Leme. Direito Ambiental Brasileiro. São Paulo: Malheiros, 2012, p.330.

${ }^{29}$ Salientamos que o Tribunal de Justiça do Estado de São Paulo já teve oportunidade de se posicionar sobre o assunto ao analisar a Lei $n^{\circ} 6.938 / 1981$ : "O exame dessa lei revela que a licença em tela tem natureza jurídica de autorização, tanto que $\circ \S 1^{\circ}$ de seu art. 10 fala em
} 
No momento atual, ressalta que, quando se está diante da necessidade de preservação de direitos fundamentais, não há propriamente, liberdade do administrador público na adoção ou não de medidas administrativas, com base em critérios de conveniência e oportunidade. Há um dever imposto ao Poder Público de atuar na defesa do meio ambiente, para garantia aquele direito fundamental já que necessário à preservação da vida e da dignidade humana. ${ }^{30}$ O que temos é um ato administrativo peculiar, que sofre fortíssima influência dos princípios que regem o direito ambiental, dentre os quais se destaca a supremacia do interesse na proteção do ambiente, em detrimento dos interesses econômicos dos particulares.

Entretanto, é inegável que tendo o administrador a liberdade de escolher entre a concessão ou não da licença, ou a sua revogação, ou seja, a margem de discricionariedade quando da análise do pedido ou sua revisão, incorre, muitas vezes, em omissões no que tange ao licenciamento, sobretudo no exercício do poder de polícia.

Argumenta-se, ainda, que tal liberdade dada ao órgão ambiental competente para exigir o licenciamento de certas atividades decorre do próprio conceito indeterminado "de atividades utilizadoras de recursos ambientais, consideradas efetiva ou potencialmente poluidoras" suscetível de ser preenchido à luz do caso concreto $^{31}$.

\section{LICENCIAMENTO AMBIENTAL E REVISIBILIDADE}

pedido de renovação de licença, indicando, assim, que se trata de autorização, pois, se fosse juridicamente licença, seria ato definitivo, sem necessidade de renovação. A alteração é ato precário e não vinculado, sujeito sempre às alterações ditadas pelo interesse público. Querer o contrário é postular que o Judiciário confira à empresa um cheque em branco, permitindo-lhe que, com base em licenças concedidas anos atrás, cause toda e qualquer degradação ambiental". TJSP, 7. ${ }^{a}$ C., AR de Ação Civil Pública 178.554-1-6, rel. Des. Leite Cintra, j. 12.5.1993 (Revista de Direito Ambiental 1/200-203, janeiro- março de 1996). Disponível em: http://www.direitodoestado.com/revista/REDE-9-JANEIRO-2007-TALDEN\%20FARIAS.pdf.

Acesso em: 15 de agosto de 2018.

30 MIRRA, ÁLVARO LUIZ VALERY. Proteção do meio ambiente: a omissão do Poder Público e o papel social do Judiciário no controle da Administração Pública, Revista de Direito Ambiental, n. 30, São Paulo: Revista dos Tribunais, 2003, p. 37.

${ }^{31}$ Nesse sentido, vide: MARCHESAN, Ana Maria Moreira; STEIGLEDER, Annelise Monteiro; CAPPELI, Sílvia. Direito Ambiental. Porto Alegre: Verbo Jurídico, 2008. 
Revisão do licenciamento ambiental segundo a literatura é a "perda da validade, no todo ou em parte, temporária ou permanente, da licença ambiental ainda no prazo de vigência"32. Entende-se, assim, como toda medida que vise adequar, anular, cassar, revogar ou suspender licença ambiental concedida, e que se encontre dentro do prazo de validade.

A possibilidade de revisão é inerente às licenças ambientais, seja pela própria principiologia do Direito Ambiental, pautado que é no princípio da precaução, seja porque são elas espécies de atos administrativos. Entende-se que qualquer ato administrativo é sempre passível de revisão se posteriormente à sua prática, houver interesse público que a justifique, como expressão do princípio da supremacia do interesse público sobre o particular ${ }^{33}$.

Nesse sentido, obviamente a Administração Pública poderá, sempre, rever qualquer ato que, supervenientemente à sua edição, se mostre contrário ao interesse coletivo, revogando-o em benefício da sociedade. Isto porque as realidades socioambiental e socioeconômica sofrem modificações que podem determinar a alteração da licença ${ }^{34}$.

Assim, o órgão ambiental competente poderá modificar, mediante decisão motivada, os condicionantes e as medidas de controle e adequação, bem como suspender ou cancelar uma licença concedida quando ocorrer qualquer das hipóteses do art.19, da Res. 237/9735.

A modificação se aplica às hipóteses em que a proteção ambiental demanda a alteração das condicionantes impostas ao empreendedor. A despeito de não haver previsão legal expressa sobre a possibilidade de modificação da licença ambiental, a doutrina defende a aplicação por analogia do art. 58, inciso I, da Lei 8.666/93, que dispõe sobre a chamada teoria da imprevisão aos contratos administrativos.

32 FARIAS, Talden. Licenciamento Ambiental: aspectos teóricos e práticos. Belo Horizonte: Fórum, 2007. p. 5.

33 Idem. Ibidem.

34 DAWALIBI, Marcelo. Licença ou autorização ambiental? Revista de Direito Ambiental, n. 17. São Paulo: Revista dos Tribunais, 2000, p. 183.

35 Art. 19: "I - Violação ou inadequação de quaisquer condicionantes ou normas legais. II Omissão ou falsa descrição de informações relevantes que subsidiaram a expedição da licença. III - superveniência de graves riscos ambientais e de saúde." 
Em relação a essa possibilidade de modificação dos padrões ambientais, a aplicação analógica da teoria da imprevisão $0^{36}$ e da cláusula rebus sic stantibus ${ }^{37}$ é implícita em todas as licenças ambientais ${ }^{38}$. Assim, diante da ocorrência de situações que, no momento da emissão da licença, eram imprevisíveis, abre-se a excepcional possibilidade de se modificar 0 ato autorizador, a fim de harmonizar o funcionamento da atividade econômica licenciada com a preservação do equilíbrio ecológico.

Nesse sentido, sempre que possível, é recomendável, como medida preliminar, a tentativa de sanear o problema mediante a modificação dos condicionantes e das medidas de controle e adequação, evitando-se a interrupção da atividade.

Entretanto, há hipóteses em que a mera modificação das prescrições ambientais de funcionamento não é capaz de solucionar o problema, não restando à Administração Pública outra alternativa, salvo operar a retirada da licença ambiental, mediante suspensão e/ou cancelamento.

Portanto, passa-se à análise das formas de revisibilidade da licença ambiental. Em primeiro lugar, suspender a licença ambiental significa sobrestá-la até que a obra ou atividade esteja adequada aos requerimentos ambientais exigidos pelo ato da concessão ${ }^{39}$. Será cabível nas hipóteses de omissão sanável de informações relevantes durante o processo de licenciamento e superveniência de graves riscos para o ambiente e a saúde, superáveis através de medidas de controle e adequação.

Por sua vez, o cancelamento da licença corresponde à própria supressão do ato administrativo, sendo cabível no momento em que esta é expedida em flagrante dissonância com a ordem jurídica, quando subsidiada por falsa descrição de informações relevantes, ou ainda, quando advirem graves riscos para o

\footnotetext{
${ }^{36}$ Aplica-se diante de "acontecimento externo ao contrato, estranho à vontade das partes, imprevisível e inevitável, que causa um desequilíbrio muito grande, tornando a execução do contrato excessivamente onerosa para o contratado". DI PIETRO, Maria Sylvia Zanella. Direito Administrativo. 13. ed. São Paulo: Atlas, 2001, p. 233.

37 "Cláusula que é considerada implícita em todos os contratos de prestações sucessivas, significando que a convenção não permanece em vigor se as coisas não permanecerem (rebus sic stantibus) como eram no momento da celebração". DI PIETRO, Maria Sylvia Zanella. Op. cit. p. 234.

${ }^{38}$ MILARÉ, Édis. Direito do Ambiente. Op. cit. p. 426.

39 MICHELS, Ruando Schlickmann. Instrumentos administrativos de prevenção ao dano ambiental. Revista de Direito Ambiental, n. 45. São Paulo: Revista dos Tribunais, 2007, p. 225226.
} 
ambiente e a saúde, porém, insuperáveis através de medidas de controle e adequação. É considerada, portanto, a medida mais drástica e, torna a licença ineficaz.

O cancelamento ou retirada da licença ambiental pode ocorrer por meio de cassação, revogação ou anulação. A cassação consiste na retirada de um ato administrativo porque o destinatário descumpriu condições que deveriam permanecer atendidas a fim de poder continuar desfrutando da situação jurídica ${ }^{40}$.

A cassação vincula-se ao problema da legalidade, mas não da legalidade da licença em si, mas de posterior descumprimento das exigências dela. Dá-se, pois, a cassação da licença quando ocorrer descumprimento: (a) do projeto, em partes essenciais, durante sua execução; (b) da lei ou de regulamento que rege a execução da obra; (c) das exigências do alvará de licença.

Já a revogação de uma licença ambiental é sui generis, pois, ao contrário do que ocorre na revogação tradicional, a retirada do ato não se dá por razões de oportunidade e conveniência do administrador, e, sim, única e exclusivamente em virtude da caracterização de uma situação excepcionalíssima de grave risco ambiental e/ou de saúde ${ }^{41}$.

Sendo assim, é indubitável a afirmação de que a revogação mesmo das licenças ambientais é ato suscetível de controle de mérito. Dar-se-á a revogação quando sobrevier motivos de interesse público que desaconselhem a realização da obra licenciada, tais como: mudança das circunstâncias, seja por haver desaparecido as que motivaram sua outorga ou sobrevirem outras que, se existissem antes teriam justificado sua denegação; adoção de novos critérios de apreciação, em que a incompatibilidade da atividade licenciada deriva de uma modificação posterior da Administração, aprovando novo plano diretor, quer modificando o existente, quer aprovando nova lei de zoneamento ou modificando a existente, com efeitos negativos para a manutenção da licença e do direito reconhecido ao particular com sua outorga; erro na sua outorga, de classificação, de valoração,

40 MELLO, Celso Antônio Bandeira de. Elementos de direito administrativo. São Paulo: Malheiros, 1992, p. 151.

41 SILVA, José Afonso da. Direito urbanístico brasileiro. 2. ed. São Paulo: Malheiros, 2000, p. 403-404. 
de interpretação ou de direito. O erro, no entanto, pode gerar uma ilegalidade na outorga da licença, caso em que seu desfazimento deverá ser feito por anulação e não por revogação $[\ldots]^{42}$.

Existe, ainda, a possibilidade de retirada da licença ambiental mediante a sua anulação. Alerta-se que anulação, que alguns preferem chamar de invalidação, é o desfazimento do ato administrativo por razões de ilegalidade ${ }^{43}$.

Observa-se que o controle de validade das licenças ambientais cabe tanto à Administração Pública quanto ao Poder Judiciário, de forma que a licença eivada de nulidade pode e deve ser anulada, administrativa ou judicialmente.

A anulação ocorrerá sempre que esta for concedida em descumprimento à Lei ou a despeito do não cumprimento de condicionantes anteriores. Assim, se um determinado empreendimento teve em seu favor concedida licença de implantação (LI) sem que tenha se desincumbido de cumprir todas as condicionantes da anterior Licença Prévia (LP), a segunda licença deverá ser anulada por ser ilegal, porque o pleno atendimento de condicionantes anteriores é condição para a expedição da próxima licença.

Neste ponto, conclui-se que a concessão de uma licença está diretamente vinculada e condicionada ao cumprimento de condicionantes da licença anterior. Verificando-se que condicionantes da licença prévia não foram cumpridas, indaga-se: por qual razão houve, por parte do órgão ambiental, a concessão de licença de implantação? E se condicionantes dessa não foram atendidas, por que razão a licença de operação se seguiu?

Do mesmo modo, constatadas alterações nos padrões ambientais, como superveniência de graves riscos ambientais e de saúde, por que não se promoveram modificações nas condicionantes e nas medidas de controle e adequação? Ou revisão das licenças já concedidas?

Vê-se que as respostas a essas perguntas podem ensejar não apenas a responsabilização do próprio empreendedor por sua ação ou omissão, dolosa ou culposa, mas tanto quanto, do órgão ambiental e servidores responsáveis pelas vistorias técnicas necessárias à análise do efetivo cumprimento das 
condicionantes - incluindo-se aí, além da violação administrativa em si, também os eventuais prejuízos ambientais decorrentes da ação ou omissão.

Portanto, ainda que a licença tenha sido concedida validamente, com observância às normas legais, cabe ao Poder Público exercer a atividade fiscalizatória pautada nas medidas preventivas e precaucionais do Direito Ambiental, diante da iminência de um dano ambiental, suspendendo ou cancelando as licenças concedidas, caso descumpridas quaisquer das condições estabelecidas anteriormente ou pela produção de graves riscos para o ambiente e a saúde.

Entretanto, o Poder Público, não raras vezes, tem se omitido no exercício do poder de polícia, o que implica em sua responsabilização civil pelos danos ambientais permitidos através de sua omissão, nos termos do art. $14, \S^{\circ}{ }^{\circ} \mathrm{c} / \mathrm{c}$ art. $3^{\circ}$, inciso IV, ambos da Lei 6.938/81.

\section{CONCLUSÃO}

Portanto, tem-se que as licenças ambientais, ao contrário das licenças comuns, são dotadas de uma discricionariedade técnica e não gozam de definitividade, podendo ser suspensas ou canceladas diante de hipóteses específicas, tais como o interesse público ou ilegalidade supervenientes, mesmo antes do vencimento de seu prazo de validade, ou quando o particular descumpre os requisitos que foram estipulados para a concessão.

É evidente que o administrador portando uma margem de discricionariedade quando da análise do pedido da licença ou sua revisão, acaba incorrendo, muitas vezes, em omissões no que tange ao licenciamento, sobretudo no exercício do poder de polícia.

Como visto, há três correntes quanto à natureza jurídica das licenças ambientais, porém, quando se está diante da necessidade de preservação de direitos fundamentais, como o direito ao meio ambiente ecologicamente equilibrado, não deve haver propriamente, liberdade do administrador público na adoção ou não de medidas administrativas, com base em critérios de conveniência e oportunidade. 
Dessa forma, mostra-se imprescindível a fiscalização estatal (pautada nas medidas preventivas e precaucionais) da licença ambiental concedida, ainda que a mesma esteja em plena vigência do ato concessório, porque as realidades socioeconômicas e ambientais sofrem modificações que podem provocar a necessidade da alteração da licença ambiental concedida ou até mesmo sua revisão nas modalidades acima especificadas.

\section{REFERÊNCIAS}

BARCEllos, Ana Paula de. Constitucionalização das Políticas Públicas em Matéria de Direitos Fundamentais: O Controle Político-Social e o Controle Jurídico no Espaço Democrático, Revista de Direito do Estado. Ano 1. n. 3. 2006. BAPTISTA, Patrícia. Transformações do Direito Administrativo. Rio de Janeiro: Renovar, 2003.

BINENBOJM, Gustavo. Uma teoria do direito administrativo: direitos fundamentais, democracia e constitucionalização. Rio de Janeiro: Renovar, 2006.

CARVALHO, Délton Winter de. Regulação constitucional e risco ambiental. Revista Brasileira de Direito Constitucional - RBDC n. 12 - jul./dez. 2008.

CUNHA, Rubem Dário Peregrino. A juridicização da discricionariedade administrativa. Salvador: Vercia, 2005.

DANTAS, Marcelo Buzaglo Dantas. Licenciamento ambiental de atividades produtivas. In: AHAMED, Fávio; COUTINHO, Ronaldo (Org.). Cidades sustentáveis no Brasil e sua tutela jurídica. Rio de Janeiro: Lumen Juris, 2009. DAWALIBI, Marcelo. Licença ou autorização ambiental? Revista de Direito Ambiental, n. 17. São Paulo: Revista dos Tribunais, 2000.

DI PIETRO, Maria Sylvia Zanella. Direito Administrativo. 13. ed. São Paulo: Atlas, 2001.

Da Discricionariedade Administrativa. São Paulo: Atlas, 1990.

FARIAS, Talden. Licenciamento Ambiental: aspectos teóricos e práticos. Belo Horizonte: Fórum, 2007.

FINK, Daniel Roberto et al. Roteiro para o licenciamento ambiental e outras considerações. In: Aspectos jurídicos do licenciamento ambiental. 2. Ed. Rio de Janeiro: Forense Universitária, 2002. 
GARCIA. Maria Gloria F. P. D. O lugar do direito na proteção ambiental. Coimbra: Almedina, 2007.

KRELL, Andreas J. Discricionariedade Administrativa e Proteção Ambiental: o controle dos conceitos jurídicos indeterminados e a competência dos órgãos ambientais. Um Estudo Comparativo. Porto Alegre: Livraria do Advogado, 2004. MACHADO, Paulo Affonso de Leme. Direito Ambiental Brasileiro. São Paulo: Malheiros, 2012.

MARCHESAN, Ana Maria Moreira; STEIGLEDER, Annelise Monteiro; CAPPELI, Sílvia. Direito Ambiental. Porto Alegre: Verbo Jurídico, 2008.

MEIRELLES, Hely Lopes. Direito administrativo brasileiro. 28 ed. São Paulo: Malheiros Editores. 2003.

MELLO, Celso Antônio Bandeira de Elementos de direito administrativo. São Paulo: Malheiros, 1992.

Discricionariedade e Controle Jurisdicional. São Paulo: Malheiros, 1992.

MICHELS, Ruando Schlickmann. Instrumentos administrativos de prevenção ao dano ambiental. Revista de Direito Ambiental, n. 45. São Paulo: Revista dos Tribunais, 2007.

MILARÉ, Édis. Direito do Ambiente. A gestão Ambiental em foco. Doutrina. Jurisprudência. Glossário. 6. ed. rev., atual. e ampl. São Paulo: Editora RT, 2009. Direito do Ambiente: doutrina, jurisprudência, glossário. 5. ed. São Paulo: Revista dos Tribunais, 2007.

MIRRA, ÁLVARO LUIZ VALERY. Proteção do meio ambiente: a omissão do Poder Público e o papel social do Judiciário no controle da Administração Pública Revista de Direito Ambiental, n. 30, São Paulo: Revista dos Tribunais, 2003. MOREIRA NETO, Diogo de Figueiredo. Legitimidade e Discricionariedade. 3 ed. Rio de Janeiro: Forense, 1998.

MOURA, Emerson Affonso da Costa. Do Controle Jurídico ao Controle Social: Parâmetros a Efetividade dos Direitos Sociais. Revista de Direito Constitucional e Internacional, v. 77, 2011.

SILVA, José Afonso da. Direito urbanístico brasileiro. 2. ed. São Paulo: Malheiros, 2000, p. 403-404. 
STEIGLEDER, Annelise Monteiro. Discricionariedade Administrativa e Dever de Proteção ao Meio Ambiente. Revista do Ministério do Estado do Rio Grande do Sul, no 48, jul.-set. 2002. 